\title{
Autonomie met perspectief. Een terreinverkenning voor toekomstige relaties van Caribische landen met Nederland en Europa
}

\author{
Lezing van prof. dr. Ernst Hirsch Ballin aan de University of Curaçao \\ dr. Moises da Costa Gomez op maandag 2 oktober 2017
}

Prof. dr. E.M.H. Hirsch Ballin*

Met erkentelijkheid voor de uitnodiging van de universiteit die mij in 1989 voor het eerst met Curaçao direct in contact bracht, leg ik u graag wat gedachten voor over perspectieven van de relaties van Caribische landen met Europa, in het bijzonder met Nederland, maar ik doe dat in het besef dat in een ander land van het Koninkrijk, Sint Maarten, de gedachten nu moeten uitgaan naar de onmiddellijke noden van onze zwaar getroffen medeburgers op dat eiland. Laten we hen ervan verzekeren dat wij ook hun leven en levensperspectieven steeds voor ogen houden als wij nadenken over de betekenis van de relaties in het Koninkrijk.

Die relaties zijn decennialang gedomineerd door constitutionele kwesties, vooral door de botsing tussen het verlangen naar autonomie op Aruba, Curaçao en Sint Maarten en de door een deel van de Nederlandse politiek te lang volgehouden opvatting dat het 'beter' is - maar voor wie precies? - dat de Antillen 'bij elkaar' blijven. Sinds 2010 is die fase afgesloten, maar nieuwe disputen doemen weer op, nog voordat de nieuwe autonomie haar waarde heeft kunnen bewijzen. Terug op Curaçao zie ik veel tekenen van een groter elan en van vertrouwen op eigen kracht in grote en kleine dingen. Maar ook weten we dat de relaties tussen Den Haag, Willemstad, respectievelijk Oranjestad en Philipsburg te vaak geprikkeld en improductief waren. De kansen van de nieuwverworven eigen verantwoordelijkheid zijn nog onvoldoende benut. Daarom wil ik graag met $u$ de gedachten proberen te bepalen op de mogelijkheid samen, over en weer, daar minder verkrampt en juist met wat meer inlevingsvermogen en wederzijdse waardering naar te kijken. Daarbij helpt het misschien om ons ook af te vragen of het Statuut voor het Koninkrijk der Nederlanden van 1954 echt als een keurslijf moet worden gezien, dan wel - misschien - ruimte biedt voor een andere kijk op de relaties in het Koninkrijk. Vaak wordt erover gesproken en geschreven alsof het een zeer rigide constitutie is, voor altijd uit te leggen aan de hand van een toelichting die in heel andere omstandigheden is geschreven, alleen met de grootste moeite te wijzigen.

* Prof. dr. E.M.H. Hirsch Ballin is verbonden aan de Tilburg University en de Universiteit van Amsterdam. 
Maar het Statuut bevat geen constitutionele theorie. Daar is het ook niet voor bedoeld. In de loop der jaren zijn er wel verschillende theoretische duidingen aan gegeven, met een enorme bandbreedte. Sommigen zien de autonomie van de Caribische landen van het Koninkrijk als voorstadium van onafhankelijkheid; anderen benadrukken postkoloniale trekken. Eén ding staat vast: de kijk op de Koninkrijksverhoudingen is voortdurend in ontwikkeling. De Raad van State gaf in 2003 twee mogelijke ontwikkelingsrichtingen aan: 'Verdieping of geleidelijk uiteengaan'.

Lange tijd heb ik gedacht en gehoopt dat we op weg waren naar verdieping in de richting van een federaal verband van gelijkwaardige deelstaten. Samen zouden we als lidstaat van de Europese Unie internationaal ertoe doen. Gelijktijdig waren er aan beide kanten van de oceaan heftige bewegingen in de tegengestelde richting: die van mentaal uiteengaan. Verschillen in optiek en politieke doelstellingen speelden hierin een grote rol.

In veler ogen is die vervreemding schadelijk: we leven in een wereld waarin verbindingen tussen mensen, organisaties en staten juist steeds belangrijker worden. Maar als de gedachte van een federaal Koninkrijksverband niet 'leeft', zullen pogingen dat te forceren een averechts effect hebben.

De tijd lijkt nu wel gekomen na te denken over een ander perspectief. Dit perspectief heeft een politiek-inhoudelijke en een constitutionele kant: die twee kunnen niet zonder elkaar. Mito Croes bepleitte dat al jaren geleden in zijn Tilburgse dissertatie; Juan David Irausquin bepleitte deze zomer in een lezing voor het Genootschap Nederland-Aruba meer ambitie te leggen in het Koninkrijksverband en gezamenlijk beleid te vormen teneinde de Sustainable Development Goals van de Verenigde Naties te realiseren. Ik ben het daar van harte mee eens, temeer daar aan die, voor de toekomst van onze kinderen en kleinkinderen zo belangrijke doelstellingen nog in geen van de vier landen van het Koninkrijk voldoende aandacht wordt besteed.

De contouren hoeven niet gecompliceerd te zijn, maar we moeten wel bereid zijn onze gevestigde meningen over wat het Koninkrijk is en hoe het werkt, te resetten. Het Statuut hoeft niet te worden herschreven - dat is als gevolg van de hoge barrières voor veranderingen haast onbegonnen werk - maar er moet wel op een andere manier mee worden gewerkt. In deze lezing wil ik verkennen hoe dat zou kunnen.

Over de voorgeschiedenis van het Statuut voor het Koninkrijk der Nederlanden is al veel geschreven, onder andere door Gert Oostindie. Vorig jaar is daar de prachtige dissertatie van Ryçond Santos do Nascimento aan toegevoegd (Het Koninkrijk ontsluierd (diss. Groningen en Aruba), 2016). Hij schrijft met veel respect over de persoon naar wie deze universiteit is vernoemd, dr. Moises Frumencio da Costa Gomez (1907-1966). De autonomie van de Nederlandse Antillen en op dezelfde voet thans van Curaçao naast Aruba en Sint Maarten is aan hem te danken. Aan de hand van bronnen laat Santos do Nascimento zien dat de juristen Van der Grinten en Van Schaik, behorende tot de Katholieke Volkspartij, op de uiteindelijke vormgeving van het Statuut overwegende invloed hadden. Zij gingen uit van een samenval van het Koninkrijk met Nederland. Dit heeft als implicatie dat er alleen tussen het Koninkrijk en de overzeese landen een verticale relatie bestaat. De autonomie van de Nederlandse Antillen en Suriname in verhouding tot het Koninkrijk is een zuivere toepas- 
sing van het beginsel van subsidiariteit uit de katholieke sociale leer. Dat Nederland de landen deze ruimte gaf zonder ze geheel los te laten, is te verklaren uit het voortduren van de koloniale beschavingsmissie. De toekenning, ten slotte, van invloed op de in wezen Nederlandse besluitvorming aan vertegenwoordigers van de autonome landen (de gevolmachtigde ministers, de bijzondere gedelegeerden in de Staten-Generaal en de staatsraden van het Koninkrijk), is met deze duiding niet in strijd. Ze beantwoordt aan het principe van autonomie binnen kaders van een subsidiair optredend moederland.

Deze duiding van de geschiedenis vind ik op zichzelf overtuigend. Constitutionele documenten zijn echter geen gestolde geschiedenis, maar leven; alleen 'originalists' op de rechterflank van de Amerikaanse rechtsgeleerdheid zien dat anders. Net als andere juridische teksten ondergaat het Statuut een voortdurend proces van herinterpretatie. Zeker sinds de Surinaamse onafhankelijkheid is van alle kanten getracht meer nadruk te leggen op de gelijkwaardigheid van de overzeese landen van het Koninkrijk met Nederland. De gevolmachtigde ministers werden gezien als gelijkwaardige collega's, ook al was hun status oorspronkelijk die van een hoogambtelijke vertegenwoordiger. Lange tijd werden besluiten tegen hun standpunt in tot het uiterste vermeden; daarin is pas verandering gekomen met het oplopen van spanningen rond de budgettaire problemen in de landen aan deze kant van de oceaan. Meer en meer is het Statuut geduid als een bijzondere federale constitutie. Zo heb ik het in mijn vroegere staatsambten en in mijn publicaties zelf ook opgevat. De tekst van het Statuut leent zich óók voor die interpretatie.

Toch is er een probleem, dat de laatste jaren steeds scherper naar voren is gekomen. Het ene is dat de legitimatie voor het Koninkrijk als federaal niveau boven de vier landen flinterdun is. Vanuit het perspectief van de Caribische landen van het Koninkrijk wordt erop gewezen dat federale wetgeving (rijkswetten) worden vastgesteld door een parlement dat - met enige uitzonderingen - niet gekozen is door de in die landen wonende staatsburgers en hen dus ook niet kan representeren. Men noemt dat het 'democratisch deficit' van het Koninkrijk. Vanuit het perspectief van de Nederlandse politiek is echter de gedachte dat Nederland zich ondergeschikt zou moeten maken aan het Koninkrijksverband, steeds minder aannemelijk. Dat heeft niet alleen te maken met getalsverhoudingen maar - helaas - ook steeds meer met een bevooroordeelde negatieve instelling ten opzichte van de Caribische delen van het Koninkrijk. Een federale staat kan alleen functioneren als er een federale nationale identiteit bestaat.

Het ene staatsburgerschap van het Koninkrijk, Nederlanderschap geheten, behoort in mijn ogen tot de verworvenheden van een op gelijkwaardigheid gebaseerd staatsverband. Daarin onderscheidt het Koninkrijk zich in elk geval van veel koloniale en semikoloniale ordeningen, zoals ook daaruit blijkt dat de inwoners van Nederlands Nieuw-Guinea net als die van bijvoorbeeld Britse overzeese gebieden het met een mindere graad van nationaliteit moesten doen: zij waren slechts 'Nederlandse onderdanen', net als vroeger de bevolking van Nederlands-Indië (Indonesië). Desalniettemin spreken wij niet van het ene Nederlandse volk, maar van de volkeren van elk der landen van het Koninkrijk; die woordkeus vinden we ook in de inhuldigingseed van de Koning. Er zijn dus in het Koninkrijk een Nederlands, een Curaçaos, een Arubaans en een Sint-Maartens volk, zij het met poreuze 
afbakeningen, want door inwoner van een ander land te worden, kan iedere Nederlandse staatsburger tot een ander volk gaan behoren.

De federale duiding van het Statuut maakt dus steeds minder kans een levende realiteit te zijn. 'Helaas' zou ik daaraan kunnen toevoegen, maar het heeft weinig zin om te verlangen naar iets dat geen realiteit zal worden. Voor het democratisch deficit bestaat eigenlijk ook geen oplossing, tenzij wij verkiezingen zouden gaan houden voor een Koninkrijksparlement, maar dat zal het nog moeilijker krijgen dan het Europese Parlement om een eigen rol te vervullen ten opzichte van de nationale parlementen.

Het lijkt mij daarom beter te denken over een andere benadering, met minder pretenties maar mogelijk een grotere effectiviteit. Daarbij neem ik als uitgangspunt dat in elk van de vier landen van het Koninkrijk een sterke wil aanwezig is om het land zelf op democratische wijze en als rechtsstaat te besturen. Er moet een route voorwaarts worden gevonden, met minder fricties en verkramping dan voorheen. De autonomie van de vier landen moet hierbij in elk geval worden gerespecteerd en versterkt. Met deze uitgangspunten valt te denken aan een in de verhouding tussen landen beproefd ander publiekrechtelijk model, namelijk dat van de associatie. Puerto Rico is een met de Verenigde Staten geassocieerd land met een eigen constitutie. Er zijn tal van niet-lidstaten met de Europese Unie geassocieerd. Associaties kunnen bestaan binnen en buiten een volkenrechtelijke eenheid, maar hier bedoel ik die binnen één volkenrechtelijke eenheid, namelijk het Koninkrijk der Nederlanden. Wanneer men de constitutionele positie van Aruba, Curaçao en Sint Maarten wil zien als een (in vrijheid aanvaarde) associatie met Nederland, dan verdwijnt de verticale dimensie van het Koninkrijk naar de achtergrond. Een land kan in vrijheid kiezen voor een associatie met een ander land: dat is een erkend internationaalrechtelijk principe.

Omdat de autonomie van de geassocieerde landen het ijkpunt is, moet het Statuut dan worden opgevat als een document dat de associatievoorwaarden regelt. Daarvoor is uiteraard wederzijdse instemming nodig, van de Caribische landen van het Koninkrijk en van het land waarmee zij zich associëren, Nederland dus. Een mogelijke inhoud van de associatie van een kleiner land met een groter land is het opdragen van bepaalde staatsfuncties - met inachtneming van waarborgen - aan dat andere land. Nederland is in deze gedachtegang niet een andere staat dan het Koninkrijk (Santos do Nascimento betoogt dat ook, op historische gronden), maar daarmee toch niet volledig identiek. Ik weet dat dit nogal mysterieus klinkt, maar in de Duitse constitutionele theorie is in de periode voorafgaand aan de hereniging de gedachte ontwikkeld dat de Bondsrepubliek Duitsland 'partieel identiek' was met de in 1871 gevormde Duitse staat. Theologen komt misschien nu ook de triniteit in gedachten. Eigenlijk zijn er maar enkele taakgebieden waarvoor zo'n opdracht van staatsfuncties in het Koninkrijk noodzakelijk is, namelijk de externe presentie als soevereine staat (buitenlandse betrekkingen, defensie en de bescherming van de eigen staatsburgers) en de interne waarborging van de fundamentele rechten van iedere Nederlander, dus als burger van een staatsbestel met de kenmerken van een rechtsstaat waarin men zich vrij kan bewegen en (her)vestigen, en kan meebeslissen over de gemeenschappelijke toekomst. Daarom moet het Statuut verankeren dat elk land een democratische rechtsstaat is en blijft; vandaar dat het gebied van mensenrechten, rechtspleging en rechtshandhaving, hoewel primair landstaken, in het belang van de burgers een common area is. 
Zo kunnen we het Statuut óók opvatten. Natuurlijk heeft dit wel implicaties. De externe economische relaties van het Koninkrijk zijn ingebed in die van de Europese Unie. Dat moet doorwerken in de interne economische relaties. Tot nu toe is daarvoor de vorm gekozen van een associatie van Aruba, Curaçao en Sint Maarten met de Europese Unie als LGO (landen en gebieden overzee). Na het verlaten van de Europese Unie door het Verenigd Koninkrijk zijn er niet meer veel landen en gebieden overzee over; mogelijk zal hun positie op bepaalde punten meer gaan lijken op die van de zogenaamde ultraperifere gebieden (en mogelijk ook omgekeerd, want ik voorzie meer differentiatie binnen de EU). Dat sluit weer goed aan bij de visie op de relatie met Nederland als een associatie. Als dat het geval is, kan de associatie als LGO blijven bestaan, maar wel nieuwe perspectieven krijgen, bijvoorbeeld de mogelijkheid op bepaalde terreinen, zoals bestrijding van terrorisme en internationale criminaliteit, echt aan te sluiten bij de EU en dus ook bij de naburige eilanden die als ultraperifeer gebied een intensere relatie hebben.

Belangrijk lijkt mij dat een structureel punt van ergernis of zelfs wederzijdse frustratie wordt weggenomen wanneer het Koninkrijk niet langer hoeft te worden ervaren als een verticaal boven de Caribische landen geplaatste laag. Het is eerlijker en daardoor minder vernederend te zeggen dat het gaat om een aan voorwaarden gebonden horizontale relatie met Nederland: mogelijk een onderhandelingsrelatie, maar hopelijk vooral een relatie met gezamenlijke doelstellingen. Aart Broek schreef onlangs in zijn boek Schaamrood. Aantekeningen over angst, agressie en ambitie waarschuwende woorden over de gevoelens van vernedering in het huidige functioneren van de Koninkrijksrelaties. In plaats ervan dat Curaçao en de andere Caribische landen van het Koninkrijk voortdurend op de tenen moeten staan om iets te realiseren wat een klein land niet kán realiseren, wordt in een associatief opgevat verband waar nodig een beroep op Nederlandse capaciteiten gedaan uit vrije wil. Dat kan bijvoorbeeld de economische ontwikkeling betreffen, het milieu en het onderwijs. Het geldt ook voor het bij de tijd houden van de wetgeving, waarvoor naast separate eigen wetten of rijkswetten, een derde weg kan worden gevolgd, namelijk het via een overnemingswet zich aansluiten bij Nederlandse wetgeving, al dan niet met afwijkingen.

Er is nog een ander, in de praktijk belangrijk punt waar deze visie op het Koninkrijk misschien wat kan helpen. In het verlengde van de visie op het Koninkrijk als een gelaagde structuur van een federaal niveau en een deelstaatniveau, is men het ambt van gouverneur gaan beschrijven als 'twee organen in één persoon'. In de ogen van sommigen gaat dat zo ver dat de gouverneur als landsorgaan zich helemaal zou moeten richten naar de ministers van de landsregering (omdat die politiek verantwoordelijk zijn aan de Staten) en als Koninkrijksorgaan naar de instructies die de minister van Binnenlandse Zaken en Koninkrijksrelaties namens de Koninkrijksregering uitvaardigt. Eigenlijk is dat toch een wat vreemde opvatting. De commissarissen van de Koning (de commissaris in Limburg wordt traditioneel, maar inofficieel gouverneur genoemd) hebben eveneens taken als provinciaal en als nationaal orgaan, maar niemand is zo dwaas hun een ambtelijke schizofrenie op te dringen.

Een minder in hiërarchische modellen gevangen visie op het Koninkrijk is ook hier van nut. Dat sluit aan bij de praktijk: de als persoon gezaghebbende gouverneurs waarmee de landen van het Koninkrijk al zo vaak zijn gezegend, hebben zich uiteraard ook niet laten 
insnoeren door de dogmatiek van twee organen in één persoon. Gelukkig maar. Hun kennis van land en landsbestuur is onmisbaar voor een ordelijk constitutioneel verkeer, onder andere, maar niet uitsluitend, in tijden van kabinetscrises. Daarom is het hun eigen kenmerkende taak om bij het vervullen van de landstaken ook de cohesie van het Koninkrijk in het oog te houden, en bij het vervullen van hun Koninkrijkstaken de autonomie van het land. Als traits d'union onderhouden zij verbindingen die passen in een geest van associatie uit overtuiging en vrije wil. Dat die taak hun is toevertrouwd, moeten zowel landsministers als Nederlandse ministers beseffen en waarderen.

Het Statuut bestaat inmiddels bijna 63 jaar. De communicatie- en transportlijnen zijn sneller en drukker geworden, de wereld om ons heen is turbulenter, tot op het onbeheersbare af. Vernietigende natuurkrachten, zoals de orkanen van dit seizoen, zijn mede door zorgeloos menselijk gedrag geprovoceerd. Het is een kwestie van verantwoordelijkheid van mensen die nu leven en over de toekomst van hun kinderen en kleinkinderen nadenken, om ons te bevrijden uit rigide, contraproductief geworden interpretatiekaders. Men heeft het zo vaak over 'historische banden'; dat klopt wel (al is het vaak een eufemisme voor het koloniale verleden) maar het moet juist om de toekomst gaan. Het Koninkrijk moet overtuigingskracht hebben, en niet alleen maar een last zijn die we met ons meetorsen omdat de geschiedenis daartoe heeft geleid. Dan kunnen we ook politieke ambities zoals die van de Sustainable Development Goals met alle kracht gaan nastreven. 